
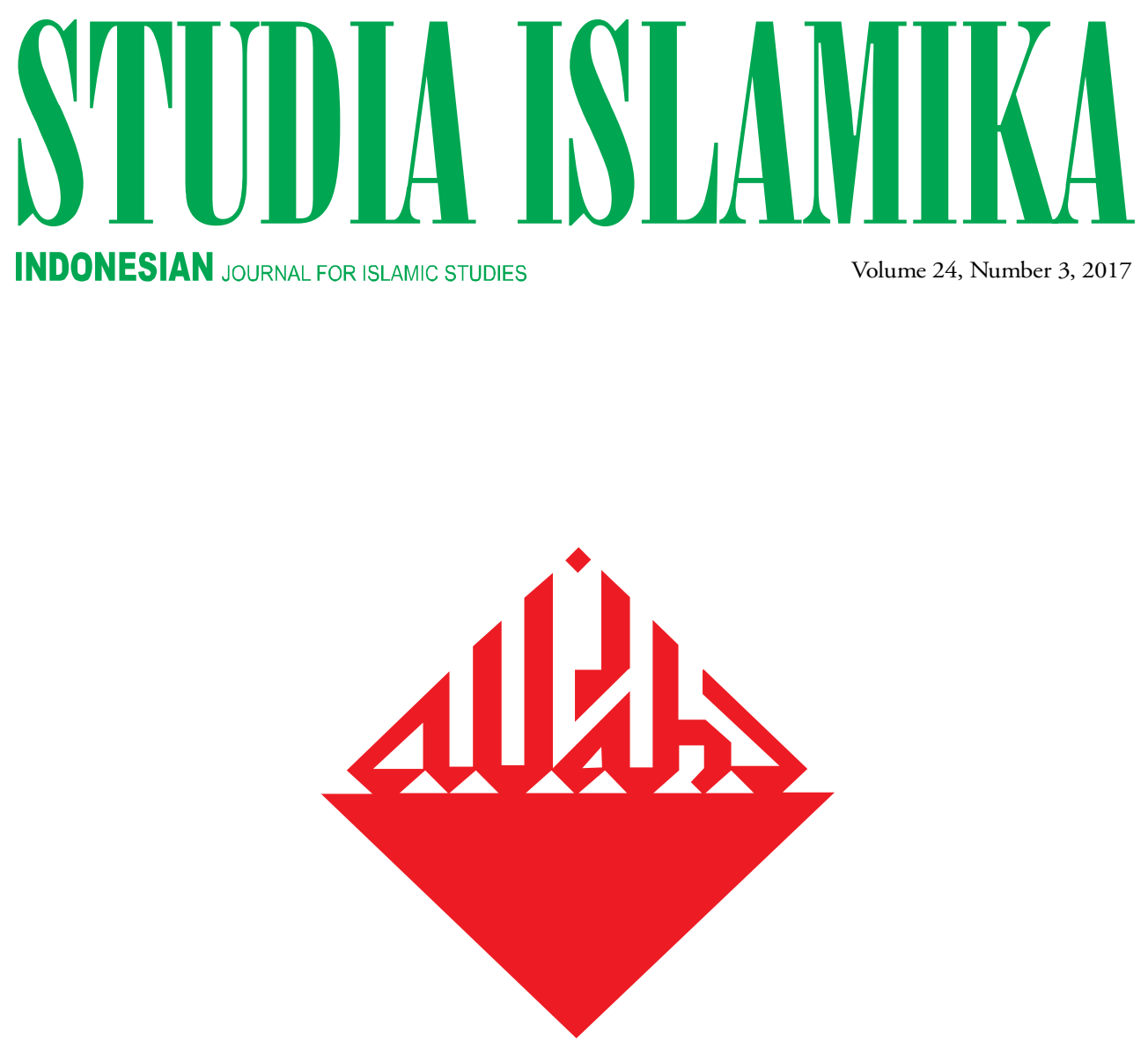

\title{
The Acculturation Strategy of the Tabut Community in Bengkulu
}

Nelly Marhayati \& Suryanto

Islamic Clicktivism: Internet, Democracy and Contemporary Islamist Activism in Surakarta Muzayyin Ahyar

The Qur'anic Exegesis, Reformism, and Women in Twentieth Century Indonesia

Norbani B. Ismail 
STIUDLA ISLAMIIIKA 



\section{STIDIA ISLAMIIKA}

Indonesian Journal for Islamic Studies

Vol. 24, no. 3, 2017

EDITOR-IN-CHIEF

Azyumardi Azra

MANAGING EDITOR

Oman Fathurahman

\section{EDITORS}

Saiful Mujani

Jamhari

Didin Syafruddin

Jajat Burhanudin

Fuad Jabali

Ali Munhanif

Saiful Umam

Ismatu Ropi

Dadi Darmadi

Jajang Jahroni

Din Wahid

INTERNATIONAL EDITORIAL BOARD

M. Quraish Shihab (Syarif Hidayatullah State Islamic University of Jakarta, INDONESIA)

Taufik Abdullah (Indonesian Institute of Sciences (LIPI), INDONESIA)

M.C. Ricklefs (Australian National University, AUSTRALIA)

Martin van Bruinessen (Utrecht University, NETHERLANDS)

John R. Bowen (Washington University, USA)

M. Kamal Hasan (International Islamic University, MALAYSIA)

Virginia M. Hooker (Australian National University, AUSTRALIA)

Edwin P. Wieringa (Universität zu Köln, GERMANY)

Robert W. Hefner (Boston University, USA)

Rémy Madinier (Centre national de la recherche scientifique (CNRS), FRANCE)

R. Michael Feener (National University of Singapore, SINGAPORE)

Michael F. Laffan (Princeton University, USA)

ASSISTANT TO THE EDITORS

Testriono

Muhammad Nida' Fadlan

Endi Aulia Garadian

ENGLISH LANGUAGE ADVISOR

Benjamin J. Freeman

Daniel Peterson

Batool Moussa

\section{ARABIC LANGUAGE ADVISOR}

Ahmadi Usman

COVER DESIGNER

S. Prinka 
STUDIA ISLAMIKA (ISSN 0215-0492; E-ISSN: 2355-6145) is an international journal published by the Center for the Study of Islam and Society (PPIM) Syarif Hidayatullah State Islamic University of Jakarta, INDONESIA. It specializes in Indonesian Islamic studies in particular, and Southeast Asian Islamic studies in general, and is intended to communicate original researches and current issues on the subject. This journal warmly welcomes contributions from scholars of related disciplines. All submitted papers are subject to double-blind review process.

STUDIA ISLAMIKA has been accredited by The Ministry of Research, Technology, and Higher Education, Republic of Indonesia as an academic journal (Decree No. 32a/E/KPT/2017).

STUDIA ISLAMIKA has become a CrossRef Member since year 2014. Therefore, all articles published by STUDIA ISLAMIKA will have unique Digital Object Identifier (DOI) number.

STUDIA ISLAMIKA is indexed in Scopus since 30 May 2015.

Editorial Office:

STUDIA ISLAMIKA, Gedung Pusat Pengkajian

Islam dan Masyarakat (PPIM) UIN Jakarta,

Jl. Kertamukti No. 5, Pisangan Barat, Cirendeu,

Ciputat 15419, Jakarta, Indonesia.

Phone: (62-21) 7423543, 7499272, Fax: (62-21) 7408633;

E-mail: studia.islamika@uinjkt.ac.id

Website: http://journal.uinjkt.ac.id/index.php/studia-islamika

Annual subscription rates from outside Indonesia, institution: US $\$ 75,00$ and the cost of a single copy is US\$ 25,00; individual: US\$ 50,00 and the cost of a single copy is US\$ 20,00. Rates do not include international postage and handling.

Please make all payment through bank transfer to: PPIM, Bank Mandiri KCP Tangerang Graha Karnos, Indonesia, account No. 101-00-0514550-1 (USD),

\section{Swift Code: bmriidja}

Harga berlangganan di Indonesia untuk satu tahun, lembaga: Rp. 150.000,-, harga satu edisi Rp. 50.000,-; individu: Rp. 100.000,-, harga satu edisi Rp. 40.000,-. Harga belum termasuk ongkos kirim.

Pembayaran melalui PPIM, Bank Mandiri KCP Tangerang Graha Karnos, No. Rek: 128-00-0105080-3 


\section{Table of Contents}

\section{Articles}

403 Nelly Marhayati \& Suryanto

The Acculturation Strategy

of the Tabut Community in Bengkulu

435 Muzayyin Ahyar

Islamic Clicktivism: Internet, Democracy and

Contemporary Islamist Activism in Surakarta

469 Norbani B. Ismail

The Qur'anic Exegesis, Reformism, and Women in Twentieth Century Indonesia

503 Muhammad Noor Harisudin

Islām wa fiqh Nusantara:

al-Tanāfus 'alá al-huwīyah wa 'alāqat al-sulțah

wa al-ramz al-dīnī li jam‘īyah Nahdlatul Ulama

555 Achmad Syahid

Al-Şumūd wa al-takayyuf wa al-tathāquf:

Ta 'bīr 'an huwìyat al-'ulamā'

fī al-manfá bi Kampung Jawa Tondano 


\section{Book Review}

617 Jajat Burhanudin

Syaikh Dāūd al-Faṭānī dan Hubungan

Mekah-Asia Tenggara: Jaringan Intelektual,

Transmisi Islam dan Rekonstruksi Sosio-Moral

\section{Document}

643 Muhammad Nida' Fadlan \& Rangga Eka Saputra Islam, Radicalism, Democracy,

and Global Trends in Southeast Asia 
Muzayyin Ahyar

\title{
Islamic Clicktivism: Internet, Democracy and Contemporary Islamist Activism in Surakarta
}

\begin{abstract}
Since the collapse of the New Order regime, social development has led Indonesia to become a more democratic and modern than any other Muslim majority countries. The development of democracy in Indonesia has also seen the proliferation of modern Islamist activism online. This form of cyber activism, named here as Islamic "clicktivism," has a discursive function. This paper examines how the proliferation of a cyber Islamist movement can be related to ongoing democratization in Indonesia. It was found that Islamic clicktivism has emerged in the process of democratization, modernization and globalization. Clicktivism encourages members of Islamist groups to adopt the principles and logic of the pillars of democracy, and to perpetuate their struggle and promote their existence during the development of democracy in Indonesia. Through their clicktivism, they bring the discursive voices of Islamism democratically to national issues in the common interest of Indonesians.
\end{abstract}

Keywords: Islamic Clicktivism, Indonesia's Islamist Movements, Democracy in Indonesia. 
Abstrak: Setelah jatuhnya rezim orde baru, Indonesia terus berusaha menjadi negara yang lebih demokratis dan modern dari negara-negara dengan penduduk mayoritas Islam lainnya. Namun perkembangan demokrasi di Indonesia diiringi dengan proliferasi gerakan-gerakan Islamis yang lebih modern; yang memainkan wacana gerakan melalui aktifisme online yang dinamakan clicktivisme Islam. Tulisan ini bertujuan untuk melihat bagaimana fenomena proliferasi gerakan Islamis via internet ini terbubung dengan perjalanan demokrasi di Indonesia. Temuan dari riset ini mengungkapkan bahwa sebagai suatu aktifitas yang lahir dari rahim kebebasan, modernisasi dan globalisasi, kliktifisme kalangan Islamis tentu menggunakan prinsip, perangkat dan pilar demokrasi agar tetap bertahan dan terus menunjukkan eksistensi di tengah pertumbuhan demokrasi di Indonesia. Hal ini dapat dilihat dari wacana yang disuarakan dalam setiap gerakan selalu membawa isu nasional yang menjadi kepentingan bersama bangsa Indonesia. Dan, semua wacana ini dapat disuarakan secara demokratis dan mudah melalui aktifisme online.

Kata kunci: Clicktivisme Islam, Gerakan Islamisme Indonesia, Demokrasi di Indonesia.

$$
\begin{aligned}
& \text { ملخص: بعد سقوط نظام العهد الجحديد، تستمر إندونيسيا في محاولتها لأن تصبح دولة أكثر }
\end{aligned}
$$

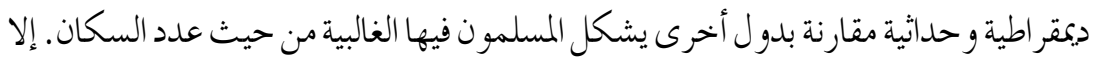

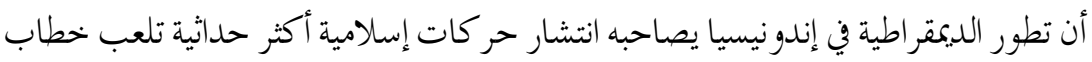

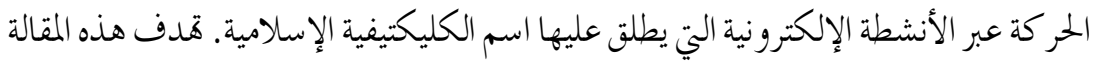

$$
\begin{aligned}
& \text { إلى إلقاء الضوء على ارتباط ظاهرة انتشار الحر كات الإسلامية عبر الإنترنت بمسيرة الديمقر اطية } \\
& \text { في إندونيسيا. ومن نتائج هذا البحث أن انتشار الأوساط الإسلامية باعتباره نشاطا ولد من إلهن }
\end{aligned}
$$

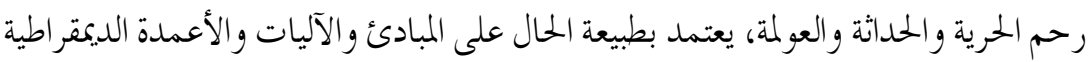

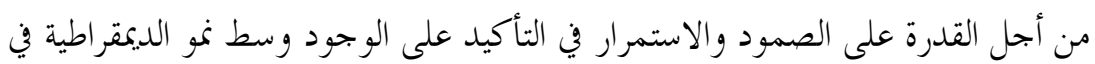

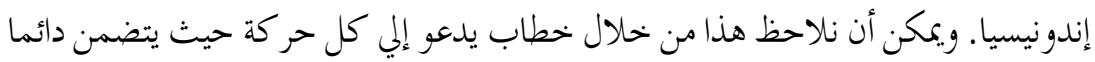

$$
\begin{aligned}
& \text { قضية وطنية تمثل مصلحة مشتركة بين الشعب الإندونيسي. ويمكن ترويج هذه الخطابات } \\
& \text { بصورة ديمقر اطية وسهلة من خلال الأنشطة الإلكترونية. }
\end{aligned}
$$$$
\text { الكلمات المفتاحية: الكليكتيفية الإسلامية، الحركات الإسلامية الإندونيسية، }
$$$$
\text { الديمقر اطية في إندونيسيا.. }
$$ 
I ndonesia continues to become a more democratic country than it was in the past. After the collapse of the New Order regime, signifying the beginning of the Reformation era, Indonesia underwent a growing upheaval of social movements with various identities, including religious identities. Some of the religious movements that have thrived since the Soeharto regime are Islamist movements and Islamic paramilitary groups, which have proliferated in major cities such as Jakarta, Yogyakarta, and Surakarta. Islamism is a term to describe the Muslim affiliates who desire to make Islam not only a value, but also a system comprising various dimensions. This term supersedes other commonly-used terms, such as fundamentalism, Islamic radicalism and Islamic terrorism, which are considered no longer relevant when discussing a religious phenomenon (Ayubi 2003; Sayyid and Sayyid 2003; Kepel 2006; Roy 1994; Hasan 2006, 2013). Surakarta deserves particular attention because of the prolific emergence of Islamist movements that have continued to grow in number from the pre-independence period until the Era Reformasi (Ahyar 2015b, 2015c, 2017).

Several of the Islamist movements in Indonesia today cannot be paralleled with those that existed in the past, such as Darul Islam. Post-reform Islamist movements have grown in line with the pace of information technology development. They exist and develop when telephone wires already hang down everywhere, internet connections are cheap and easy to establish, sophisticated smartphones with a variety of applications are commonly available, and Wi-Fi is accessible in almost every public space, even in the mosque.

The development of democracy, technology and the growth of Islamist movements have shown a linearity that highlights how intertwined they are with one another. In the information era, jihadist movements can no longer be referred to as anti-modern or avoiding technological development. In fact, modernity has become a complementary tool for marketing jihad fights (Barber 2003).

The Islamists, who were commonly known as reclusive people and opposed to modernity and democracy, are now quite open in using modern technology to spread their influence among the wider community. For instance, the frequent broadcast of the struggle of the Islamists to defy a corrupt government, tāgh $\bar{u} t, z \bar{a} l i m$, is without Sharia implementation in state orders. 
These viral broadcasts often develop among the Muslim middleclass in Indonesia, and clearly produce a new discourse. The activity of spreading this discourse is called "clicktivism," a term which emphasizes cyber activism using modern technology to spread information widely and on a massive scale. Clicktivism has the characteristics of a real movement, exhibited by stating demands in the streets, and forcing policy makers to negotiate with the Islamists. The frame, messages, and structures of the identity of Islamist movements are conveyed democratically through this clicktivism process and finally they make online enclaves which produce multiple forms of nationalism in the democratic country (Lim 2013, 2017).

Amid the increasing application of technology devices (smartphones/ gadgets) within the Indonesian Muslim middle-class, clicktivism has become a combined activity of both reading and sharing information. Various social media (such as WhatsApp and Blackberry Messenger) have developed the "broadcast" feature to make sharing activity easier. Information sharing to hundreds of people can occur with just one "click" or "touch," with the information rapidly spread locally, nationally or internationally.

Moreover, the democratic principle of the freedom of assembly, and even the right to criticize the government without the accusation of subversion, makes clicktivism a new arena of social movement in the context of civil society.

This paper seeks to comprehend how this phenomenon is related to the nation's ongoing democratization and the current proliferation of radical Islamist activism. Some questions emerge from this inquiry: what are the social and political meanings behind the proliferation of Islamic clicktivism? How widespread is this clicktivism, and what are its supporting factors? How can Islamic clicktivism successfully become a real movement in Indonesia, involving various Muslim civil society groups?

\section{Finding Islamism and Technologically Literate Islamists in Surakarta}

Solo, the more commonly used name for the city of Surakarta, has become the focus among scholars studying Islamism movements and Islamic activism in Indonesia. I have therefore chosen to study Islamism in Solo and relate it to the development of information technology, 
democracy and social movements in Indonesia, and in particular Islamic clicktivism. This study of Islamic clicktivism in Solo is focused on understanding the role of the internet (especially social media and online messengers) in tabulating and disseminating information. Some of the information processed through social media can lead to real action, supported by various groups even from outside of the ideology of Islamism, but other information is limited to becoming sporadic, internal action involving only their own small groups.

The emergence of several Islamic vigilante groups, as a sign of the proliferation of the Islamism ideology in Solo, is not a new phenomenon. The origin of the Islamist movement can be traced back to the pre-independence era. In the Dutch colonial period, an early Islamist movement was established, known as Sarekat Islam (SI, Islamist Union), formerly Sarekat Dagang Islam (SDI, Islamist Trade Union). In the years following Indonesia's independence, the Islamist movement has mushroomed in every single transition period of Indonesia's political regime.

In Indonesia's post-independence era, Sekarmadji Maridjan Kartosuwiryo proclaimed the Darul Islam movement on August 7, 1949, in Cisampak Tasikmalaya. Darul Islam is a movement that struggles for the separation of its own territory from Indonesia, and to establish an Islamic, Sharia-based government. In the New Order regime, Abu Bakar Ba'asyir founded Jamaah Islamiyah, the South-East Asia trans-national Islamist organization.

After the fall of Soeharto's authoritarian regime, some Islamist movements have emerged sporadically to establish their Islamism identity in the public sphere. In this democratization period, local Islamist groups that have emerged in Solo include Laskar Jundullah, which is the right wing of Forum Komunikasi Aktivis Masjid (FKAM, the Communication Forum of the Mosque Activist 1999), Laskar Hizbullah, 1999, Front Pembela Islam Surakarta (FPIS, Surakarta Islamic Defender Front, 1999), Tim Hisbah, and Laskar Umat Islam Surakarta (LUIS, Islamic Vigilante Group of Surakarta, 2000). A less familiar Islamist movement is Front Pemuda Islam Surakarta (FPIS, Muslim Youth Front of Surakarta). FPIS was formed in 1999 by some people who basically became jama'a pengajian Gumuk (Wildan 2008). In this historical background of the emergence of Islamist activism in every period, there is a special feature of the transformation. It shows 
the trend of significant transition from the underground jihadists of Islamism, to a peaceful Islamism with a democratic strategy. The following Islamism discussion focuses upon contemporary Surakarta, and refers to the emergence of peaceful Islamism with a democratic strategy as the result of a long dialectical process between the ideology of Islamism and modernism.

During my intensive fieldwork, some members of $i k h w a n / I s l a m i s t$ groups - it is more convenient to use the term "ikhwan" than Islamic activist - were willing to share their experiences in movement actions. They come from various regions around Surakarta; Semanggi, Bekonang, Kartasura, Purwosari and Tipes. I met the ikhwan in various places, such as mosques, markets, HIK, ${ }^{1}$ and even in the prison of the City Resort Police in Manahan Solo. They were generally between twenty and forty years old. Some of them were well educated, graduates of famous universities in Central Java like Universitas Sebelas Maret (UNS), Universitas Jendral Soedirman (UNSOED), Universitas Muhammadiyah Surakarta (UMS) and Institut Agama Islam Negeri (IAIN, State Institute for Islamic Studies). Yet the majority of the ikhwan majored in nonreligious fields, such as engineering, advertising, management and law.

Other members were high school graduates and worked in entrepreneurial roles with clothing merchants, coffee shops, grocery and plastics stores, parking services and construction work. Moreover, among the members of this movement were teachers in public schools that held the status of a Pegawai Negeri Sipil (PNS, Civil Servant). Indeed, this is a contradictory and unique phenomenon, seeing the bearers of the ideology of Islamism in the scope of non-Islamic government, while being a servant of the Indonesian state. They get a living, a salary and other privileges from a democratic state, yet they say that democracy in Indonesia is an infidel state system, with an apparatus regarded as anșār al-țäghüt (the helpers of accursed disbelievers).

Some activists of the Islamist movement claim they were born from an abangan family, and had less education in Islamic doctrine when they were children. It is very different from kaum santri (people who study in Pesantren Islamic school), who understand Arabic grammar earlier, and study some Arabic magnum opuses composed by classical scholars like Nu'man ibn Thābit or Abu Hanīfah (80AH/699AD 148AH/767AD), Mālik ibn Anas (93AH/714AD - 179AH/800AD), Muhammad Idrīs al-Shāfíī (150AH/767AD - 204AH/819AD) and 
Ahmad ibn Hanbal (164AH/780AD - 241AH/855AD). They are generally familiar with Islam in the Reformation era. Some of them still stammer when reciting the Quran and other Arabic books that are unaccompanied by punctuation. They studied classical Islamic sources through short lectures in various places. Because of their lack of Arabic grammatical knowledge, the Arabic-Indonesian translated books of some Ulama and Islamic scholars mean a lot to them. Actually, they derive their Islamic views from their senior activists, especially Abu Bakar Ba'asyir, and Aman Abdurrahman; two central Islamist figures in Indonesia. In addition, some Islamic articles on various websites with political Islam nuances are also a source for them. ${ }^{2}$

The ikhwan are not only found in mosques, but also in traditional markets, motorcycle and car washes, and pedi cab hubs. Some of them are also on the street corner, selling prepaid cellular phone credit at the stall, or peddling fresh milk on the car. Their clothes are not always in Arabic style, with a dangling cloak. Ikhwan between 20 and 30 years of age look like any other young, urban and modern people in Indonesia; wearing jeans or trousers with stripes and a lot of army style pockets, or current fashion shirts with Islamic slogans written in English, like "Islam is our choice." Some have tattooed wrists engraved with dragon drawings or other writing. This phenomenon appears to confirm that many of them previously lived in the "dark world." The only difference in clothing style between them and common people is pants that are above the ankle. Whatever they wear, the ikhwan always avoid pants that dangle down over the ankle (isbāl).

Considering the ikhwan's life from the economic side, they can be categorized from lower to middle class in society. This is based upon the Asian Development Bank's classification, agreed upon by the World Bank, which stipulates that the middle class are those with per-capita daily expenditures between USD 2 and USD 20, or approximately IDR 26,000 - IDR 260,000. The per-capita expenditure span is subdivided into three groups: lower middle class with daily per capita expenditure about USD 2-4, median middle class at about USD 4-10; and upper middle class about USD 10-20. ${ }^{3}$

The middle class classification does not prevent the members of Islamist groups from buying technology devices. In the current climate of consumerism among Indonesian people, some smartphones with the latest technology are sold at an affordable price for the middle class. For 
IDR 800,000 (about USD 60), it is possible to buy a simple smartphone with a variety of social media and online messenger applications, such as Facebook, Twitter, Instagram, Whatsapp, Blackberry Messenger, and Line. The variety of applications are not only used by the ikhwan for leisure, but as a strategic instrument for developing the discourses of Islamism and the dissemination of information on a large scale. For the dissemination of information among a broad audience, Facebook is considered the most effective. As for the dissemination of internal information and the consolidation of group power, Whatsapp messenger is used. Ikhwan learn from each other and share their ability in using gadgets and social media applications. Among several messenger applications, Whatsapp is rated as easier to use, and has the contact capacity to create a chat group. Each member of an Islamist movement holding a smartphone claims that they have more than one chat group within the circle of Islamist identity groups in Solo.

\section{Islamism and its Activism in Indonesia: Some Cases}

The term Islamism in this study is based upon Nazih Ayubi's work on Islam and political discourses in the Arab world. Ayubi argues that is necessary to categorize the types of Muslim, because it will help us understand the struggle discourses in religion, politics and social movements in Islam. Thus, Ayubi categorizes Muslims into several groups, which he calls a "taxonomy of Muslim behaviour toward political order" (Ayubi 2003). This taxonomy is of his own construction, introduced to simplify explanations of various models of Muslim behavior, in relation to their beliefs. The first category is the simplistic Muslim, or those who were born as a Muslim or born to Muslim parents, and whose name is identically "Islam," such as Ahmad, Muhammad, Ali, Aisyah, Fathimah, and so forth. The second category is the mutadayyin Muslim. This is an observant Muslim, who upholds the dogma of Islam (shahadatayn, two credos of Islam), fulfills the duties of prayer, fasts in Ramadhan month, goes on a pilgrimage (hajj), and pays $z a k a \bar{h}$. Various levels of piety may be expressed through some good work. This level of Islamicity does not have a radical ideology of the unity of Islam and the state or politics.

The third category of Muslim is the Islamic reformer or Islamic modernist. Notable figures in this group include Jamāl al-Dīn alAfghānī and Muhammad 'Abduh. The Islamic modernist believes that 
Islam is the perfect system of faith, but it is somewhat flexible to adapt with modern developments, including in political and governmental systems.

The fourth category is Salafism. It emphasizes that human behaviors ('ibaddah and mu'amalah) have to refer to the authentic sources of Islam (Quran, Sunnah, and the tradition of earlier Muslim generations). Salafism is more scriptural and traditional in its understanding of Islam, as represented by Wahäbìyah, Sanūsìyah, and Mahdīyah, but sometimes it is more flexible towards political and governmental order. The other examples of Salafism are groups affiliated with the Ikhwān alMuslimin and Hasan al-Banna. Characterizing the Ikhwän al-Musliminn as Salafist, however, is debated among scholars.

The final category is fundamentalism (in Arabic, al-usülìyün). Fundamentalism is more complex and difficult to define. Like Salafism, fundamentalism also calls Muslims to refer to the authentic sources of Islam, but it is less sympathetic to fiqh. Fundamentalism argues that fiqh only becomes the unity destroyer of ummah because of taqlid or "blind fanaticism" toward the imàm al-madhhab (chief of sect). Fundamentalism considers Islam holistically and comprehensively through the "three Ds." Specifically, Islam is meant to be din (a religion), dunyā (a way of life), and dawlah (a state). These holistic notions are significant for implying the need for collective action, or to bring Islam to the fighting ground. There are also splinter groups within fundamentalism, such as neo-fundamentalism. This group is usually more radical or militant in orientation than other Islamic groups. Neo-fundamentalism is also more inclined towards immediate action. Examples of this group include the takfîri in Egypt and Islamic State in Suriah. ${ }^{4}$

The term Islamism is applied to the last three categories (Salafism, fundamentalism and neo-fundamentalism). Islamism not only emphasizes Islam as an identity but also as the instruction manual for life. Indeed, the Islamism movements are not singular, as some of them emphasize militancy, and others target the social elite and grassroots levels of society. Bassam Tibi, a Muslim scholar concerned with the Islamism discourse, argued that these Islamist movements have a similar vision to change the world order. According to some scholars, the world order is a profane order, but according to the Islamist, it becomes the sacred order. They imagine world hegemony in the arms of al-Dawlah 
al-Islämìyah and hakimiyātullāh. Because of the sacred order, they must expand into international Muslim discourses. According to Tibi, overthrowing the secular regime (like what is happening now in some Middle East countries) is only the first step in an effort to create a new world order. The main goal of Islamism is to challenge the secular world order, which means to challenge the West. Tibi seems to be explicit in his argument to reject Islamism. According to Tibi, Islamism is not similar to Islam because Islamism contrasts with the universal values of Islam as the religion of rahmatan li al-álamin. Islamists have the ambition to introduce an Islam that is not merely teachings about the "love of god," but also a set of tools that have to be used politically to control the world (Tibi 2002).

Some scholars and intellectuals have argued there is evidence of a paradigm shift from an Islamism ideology to a post-Islamism era, indicated by the acceptance of Islamists against the systems of society, economics, politics and law enforcement that are more flexible in modern times (Bayat 2007). However, in this paper I still use the term Islamist/Islamism to refer to small groups in Solo who desire to propose Islam not only as a value, but also as a system that includes many dimensions of life (i.e. Islam is a way of life). I still use the term Islamism, since local Islamist movements in Solo have not been transformed into the political system of the state like a number of post-Islamist groups, such as Partai Keadilan Sejahtera (PKS, Prosperous Justice Party) in Indonesia, Adalet ve Kalkinma Partisi (AKP, Justice and Development Party) in Turkey, Parti de la Justice et du Dévelopment (PJD) in Morocco, or the political system in Iran. Islamist movements in Solo still exist outside the boundary of the Indonesian political arena. On the one hand, they fight in various discourses through virtual and real activities, and they continue to reject democracy as a global, modern political system. On the other hand, they participate in the democratic process by criticizing the government through the media, real or virtual social movements, and engage in cyber activism (networking and mobilizing the masses via the internet). The following discussion presents some cases of "virtual to real" activism by Islamists groups in Solo.

\section{Rejection of the Establishment of the Iranian Corner at IAIN Surakarta}

In early May 2014, some Youtube videos describing the different religious interpretations of the Shia sect were widely spread across 
social media to Islamist activists around Solo. The video became the postulate and the legitimizer of the Shia heresy because it was considered different from the worshipping of the Muslim majority in Indonesia. The spreading of the (viral) video triggered protests against the proposed Iranian Corner that was to be built at the Institut Agama Islam Negeri (IAIN, State Institute for Islamic Studies) in Surakarta. This center of study has been established in several universities to discuss educational and cultural issues in Iran. The establishment was attended by Mahmoud Farazandeh (Iran Ambassador for Indonesia), and Hojjatullah Ebrahimian (Consulate General of Culture Iran Embassy). As the video and its heretical messages spread, some actors from the Islamist movements in Solo, under the command of Laskar Umat Islam Surakarta (LUIS, Islamic Vigilante Group of Surakarta), attempted to formally reject the plan by sending official letters to concerned parties, including the rector of IAIN Surakarta, dean of the Faculty Ushuluddin and Da'wah, and Majelis Ulama Indonesia (MUI, The Indonesian Council of Ulama) in Solo, in order to raise awareness of the spread of the Shia sect in the region.

The rejection intensified on the premise of maintaining Islam as a pure religion, amid concerns that Shia deviated from traditional Islam, which claimed that true of Islam is only on one school; Ahl al-Sunnah wa al-Jamäah (Sunni school), and that its growth would tarnish the purity of Islam in Indonesia. The concern was, with the establishment of the Iranian Corner at IAIN Surakarta, Shiite doctrine would infiltrate the Islamic Universities. ${ }^{5}$

Laskar Umat Islam Surakarta (LUIS, Islamic Vigilante Group of Surakarta, the biggest and most organized Islamism group) stated their disapproval in several stages. First, LUIS sent a letter to IAIN as a hard reminder about the danger of Shia in Indonesia. IAIN responded by holding a dialogue between LUIS and IAIN. The results of the dialogue were considered ambiguous by LUIS, which thought that the Iranian Corner would still be established.

In response to that, LUIS mobilized the masses to protest the plan. On May 21, 2014, LUIS yelled takbir loudly and ferociously. They organized a rally in front of IAIN Surakarta and denounced the profanity, desecration and heresy of the Shia, which they considered a distortion of Islam. To avoid anarchy, the rally had to be guarded by the police and military. It ended after a long and tough dialogue 
among many parties with IAIN, resulted in the cancellation of the Iranian Corner, and required IAIN Surakarta to end cooperation with the Embassy of the Islamic Republic of Iran. ${ }^{6}$ The discourse about the Muslim majority and "deviant" sects has not stopped since law against religious blasphemy was introduced. Some cases of religious blasphemy corroborate the conflict between state and ulama (national legalformal vis-à-vis the authority of fiqh) in determining the legitimate interpretation of law and Islamic law in Indonesia (see Alfitri 2008, 2015). The "deviant" sects, like Ahmadiyah and Shia, have two confusing scopes, with both religiosity and nationality problems (Ahyar 2015d; Widyantoro 2017).

\section{The Case of the Rejection of the Illegal Church}

The issue of Kristenisasi (Christianization, missionary activism for spreading the Christian or Catholic religion) has been proliferating since the New Order regime in Indonesia. One Muslim perception of Christianization relates to the building of Christian churches, prayer places and other Christian institutions or organizations in Muslim majority communities (Narciso 2008). Currently, protests against Christianization are often conducted by Islamist movements in Indonesia, especially in Solo. Since November 2014, there have been reports about the demand for the closure of Gereja Kristen Indonesia (GKI, Indonesian Christian Church) in Busukan village, Kelurahan Mojosongo Solo. The residents consider the church's existence disruptive, and believe it will damage inter-religious harmony in the area. Further, there is an issue with the legality of the establishment of the church building. The messages of rejection against the church began to spread virally through the internal social media groups of the movements, and was followed by the mobilization of the masses, using the signatures of the residents in Mojosongo in a petition to close down the church. After the signatures were collected, they placed banners announcing the residents' rejection of the establishment of the church. This rejection movement was presented by the actors to the relevant agencies, including some Islamist movements in Surakarta. Finally, on Friday, November 28, 2014, at about 13:30 at the office of the village of Mojosongo, there was a dialogue among the actors, residents, church representative and the government. ${ }^{7}$ At that time the deputy mayor, Ahmad Purnomo, asked for a month to verify the data. 


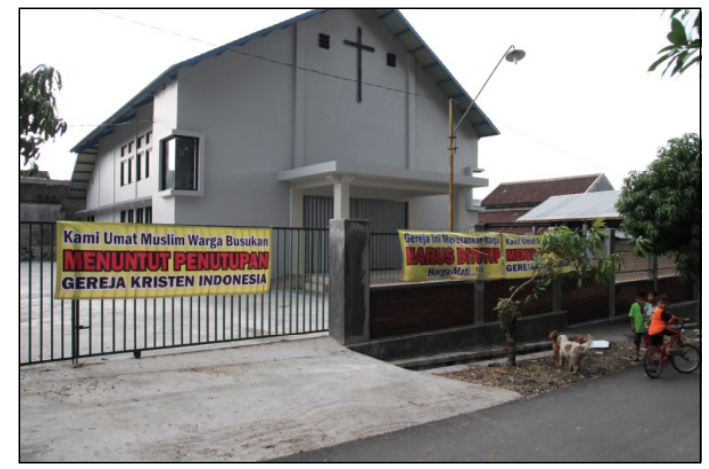

Figure 1. Banner rejecting the church.

Source: panjimas.com

After the formation of the verification and investigation team of the illegal church, some movements that were affiliated with or based on the Islamist ideology showed the case of the closure of Gereja Kriten Indonesia Mojosongo in various online media like Panjimas (local media in Solo) and Voa-Islam. This news was then spread throughout Facebook pages (Anti-liberal News, Salam Satu Jari DIY dan Jateng), and became viral messages in communities affiliated with the Islamist ideology. In this case, Gereja Kristen Indonesia Mojosongo was closed temporarily after the data verification team found there was no legal permit for building the establishment.

\section{Justice Demands for the Anti-Liquor Activists}

The third case involved six Islamist activists who persecuted citizens who drank alcohol. Three civilians were persecuted by activists policing drunkards. The case regards a group of young men engaged in "sweeping" the drunkards in Baturono Solo in March 2015. They were eventually taken into Surakarta police custody. In this incident, the young men of the Tim Hisbah were reported to police by a few people who claimed the Islamist activists physically abused them during the raid. Tim Hisbah is one of the local Islamism movements that developed in Solo, Central Java (see Ahyar 2015). In less than 24 hours, these six Islamist activists were caught by police officers and arrested for about a week. During the custody period, another member of the Islamist group contacted Tim Pengacara Muslim (TPM, Muslim Lawyer Team) and asked them to become their counsellor. 
Because of the incident, some civilians interested in the Islamist movements in Solo claimed renewed spirit for defending the six activists of Tim Hisbah arrested by the police officers. They formed a new advocacy group called the Tim Advokasi Umat (TAU, Advocacy Team for Umat), comprised of 12 certified advocates. Muhammad Kalono, a senior actor in Islamist movements in Solo, chairs the Tim Advokasi Umat. Of the 12, three were not from the network of Islamist movements in Solo. They demanded justice for two persons, Agus Junaidi and Rudi, who were not thought to be involved in the violence, but instead only visitors to the site after the "sweeping" raid occurred. The actors of the movements considered the incident a violation of the law regarding the distribution of liquor, and believed it discredited Islam, as a religion whose doctrine prohibits liquor. ${ }^{8}$

In reaction and protest against the arrests, Islamic activists tried to mobilize the masses through online news media, which spread virally until Tim Advokasi Umat was formed to advocate for the Islamist activists and seek justice for them. Tim Advokasi Umat was claimed as a success for the group of Islamist activists in Solo as they highlighted the injustices of law enforcement experienced by the Islamic movements. ${ }^{9}$

\section{The Siyono Case}

The fourth case is that of Siyono, a villager of Pogung Klaten, Central Java, who was suspected of terrorism, and died when arrested by Detachment 88 anti-terror police. On March 8, 2016, Detachment 88 arrested Siyono while investigating terrorist acts and firearm possession. When brought to the site of the inspection, members of Detachment 88 reportedly beat Siyono until he was unconscious. After the incident, Siyono was taken to the Bhayangkara hospital in Yogyakarta, but died on the way. On March 10, 2016, Detachment 88 returned to Siyono's house to conduct further investigations and search for evidence. On March 12, 2016, news emerged about Siyono's death, which was blamed on his resistance when being investigated. Siyono's wife, who discovered strange details concerning Siyono's death, announced this to several parties, such as the Komisi Nasional Hak Asasi Manusia (Komnas HAM, National Commission on Human Rights) and the Islamic organization, Muhammadiyah. After the news of Siyono's death, some media affiliated with the Islamist ideology covered the story, and wrote about it in their online news portal. ${ }^{10}$ 


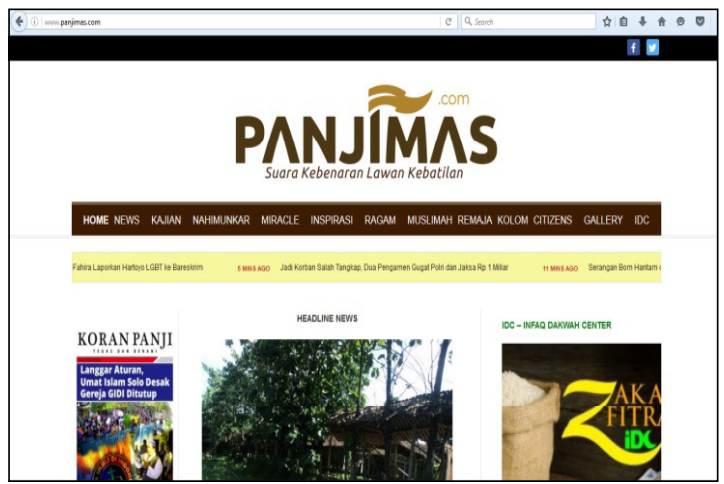

Figure 2. Islamist Media for spreading discourses

Source: http://www.panjimas.com/

The demands of various parties for an autopsy of Siyono's corpse were successful. In fact, Muhammadiyah was ready to mobilize the youth fighters of Komando Kesiapsiagaan Angkatan Muda Muhammadiyah (KOKAM, Muhammadiyah Youth Preparedness Forces Command) to guard the corpse during the autopsy. The obituaries of the terrorist suspect spread virally, especially among the people of Solo. As a result, various civil society movements urged for transparency by the national police in relation to Siyono's death.

In Solo, hundreds of people moved along the Slamet Riyadi street, protesting the obscurity of the arrest procedure for Siyono. Komnas HAM urged the national police to be more transparent, and prosecute the case if there was an error in the arrest procedure. In addition, Komnas HAM also fought for the victim's family's right to justice. The Muhammadiyah viewed the Siyono case as corruption, as Detachment 88 had offered 100 million to the victims' families. ${ }^{11}$

These four cases are examples of cyber movements that contributed to social change, and the identity struggle process in democratic circumstances. In the case of the rejection of the Iranian Corner and the closure of the illegal church, it is demonstrated that they are trying to grow public awareness through online media relevant to their identity. In these cases there has been a fight for global identity through local action. The identity struggle between Sunni and Shia Muslim groups is a global discourse. The discourse relating to the rejection demonstration against IAIN Surakarta, considered a dangerous situation that could trigger local conflicts, meant they had to solve the problem with a radical rally to protest the establishment 
of the Iranian Corner. The discourse about the relationship between Christianity and Islam is a global identity discourse, but was achieved with local action in the case of the rejection of the church, due to legal issues regarding the development. As a result, the movement and the protest were limited internally to the group, and did not become a common issue.

In the examples of the second and third movements, the actors encouraged more Muslim civil society groups to be involved in responding to the issue. The variety of people who responded to the issue is reflected in the identity of the group. It can be further seen in the following table:

\begin{tabular}{|c|c|c|c|c|}
\hline \multirow[b]{2}{*}{ Action/Case } & \multirow[b]{2}{*}{$\begin{array}{l}\text { Responding Group / } \\
\text { Involved movement }\end{array}$} & \multicolumn{3}{|c|}{$\begin{array}{c}\text { Narrative } \\
\text { Identity/ideology }\end{array}$} \\
\hline & & $\frac{\breve{n}}{\underline{\Xi}}$ & 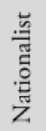 & 랠 \\
\hline \multirow{4}{*}{$\begin{array}{l}\text { Rejection of Iranian } \\
\text { Corner }\end{array}$} & Laskar Umat Islam Surakarta (LUIS) & $\checkmark$ & & \\
\hline & $\begin{array}{l}\text { Dewan Dakwah Islam Indonesia (DDII, } \\
\text { Muslim Da'wa Council of Indonesia) }\end{array}$ & $\checkmark$ & & \\
\hline & $\begin{array}{l}\text { Communication Forum of Mosque Activists } \\
\text { (FKAM) }\end{array}$ & $\checkmark$ & & \\
\hline & $\begin{array}{l}\text { Harakah Sunniyah for Islamist Society } \\
\text { (HASMI) }\end{array}$ & $\checkmark$ & & \\
\hline \multirow{2}{*}{$\begin{array}{l}\text { Closure of Illegal } \\
\text { Church }\end{array}$} & Laskar Umat Islam Surakarta (LUIS) & $\checkmark$ & & \\
\hline & Tim Hisbah Solo & $\checkmark$ & & \\
\hline \multirow{3}{*}{$\begin{array}{l}\text { Advocating to Sporadic } \\
\text { action of anti-liquor } \\
\text { activist }\end{array}$} & Tim Hisbah Solo & $\checkmark$ & & \\
\hline & Laskar Umat Islam Surakarta (LUIS) & $\checkmark$ & & \\
\hline & Independent Scholars / advocates & & & $\checkmark$ \\
\hline \multirow{4}{*}{$\begin{array}{l}\text { Defense of Siyono, } \\
\text { terrorist suspect }\end{array}$} & Laskar Umat Islam Surakarta (LUIS) & $\checkmark$ & & \\
\hline & Tim Hisbah & $\checkmark$ & & \\
\hline & Muhammadiyah & & $\checkmark$ & \\
\hline & Komnas HAM & & $\checkmark$ & \\
\hline
\end{tabular}

Table 1. List of group/movement and group identity in emerging case/action

\section{Internet and Cyber Activism}

The development of technology has influenced several social and political dimensions. In the information field, the development of technology has revived mass distribution of information. In the mid-19th century, information about political activities was spread through print media as a result of the industrial revolution. Following that, technology advanced rapidly and delivered the media that can visualize completely: television. However, some information media are not accessible to all people due to the cost, meaning only the rich 
are able to use it. The limitation of the media in the political arena can be considered in opposition to the democratic values of universal participation in political activities and the ability to convey aspirations to the government.

In the 1980s there was a resurgence of information media for democratic societies. The internet became the new medium. For decades, the internet has reached more broadly across society. Various internet services have developed, such as BITNET (Because it's Time to Network) and CSNET (Computer Science Network), which provide electronic mail services (e-mail). As the development of services advance the virtual world, there are new communities that never meet in the real world, instead communicating primarily in the virtual world in virtual communities (Rheingold 2000; Chadwick 2006).

In the political arena, the internet has impacted the transformation of patterns of social movements. Here, a social movement is often defined as networks of informal interaction between a plurality of individuals, groups/or organizations, engaged in a politial or cultural conflict on the basis of a shared collective identity. With the proliferation of internet use worldwide, social movements have become more intense because it has made mobilization easier.

Cyber activism raises some arguments for social movement scholars. The earlier academic theories explaining the success of social movements argue that social change action occurs because massive collective identities exist in movements, and also because the movement has the ability to frame the issue. The success of social movements is also indicated by the resources readily available to mobilize in the movement group: money, media, and the movement followers (Tilly 1978). Yet, an earlier theory of social movements raises the question of how collective action, resource mobilization and certain movements impact social change? Here, Sidney Tarrow presents an example of how political opportunities can factor in the social movement's ability to make an impact. Tarrow provides some cases of labour protest activism that occurred in social movements in Western Europe and the United States. Tarrow concludes that labour insurgency could occur because of the new opportunities created by the state, and not worker resources. So, the arguments of political opportunities theory not only shows the power of movements, but also examines the state's strength and repressiveness (Tarrow 1998). 
Strategic use of the internet by Islamists is a new variant in the discourse of Islamic activism, and is considered effective and efficient. In the case of Palestine, the resistance of Palestinian youths using the internet became the latest trend after the outbreak of the second intifäda in the mid-2000s. Political activism on the internet is a politically conscious effort, and proves the growth of Islamist activism in young people in Palestine. The real world resistance movement has taken too many casualties; statistical data recorded from 2000 to 2008 reveals there were 2967 young men killed in the Israelioccupied territories. Since that time, the resistance movement has mass mobilized electronically through social media, the deployment of video to attract sympathizers, and an online petition for fundraising. Through the internet, young people can be connected with the world and enabled to create international humanitarian projects such as PYALARA (The Palestinian Youth Association for Leadership and Rights Activation) for the liberation of Palestine, with the support of international NGOs (Makram Khoury-Machool; Bayat and Herrera 2010).

In relation to internet use as a basis of activism, Saiyan Chattopadhyay conducted a special study on online activism in India. In early 2009, a gang of approximately twenty men brutally attacked a group of young women partying inside the Amnesia Pub at the Hotel Woodside in the Balmatta area of Mangalore, India. Following the attack, Bajrang Dal, an activist of the radical youth wing of the Vishwa Hindu Parishad (VHP), claimed responsibility, as a form of protest reaction against women who considered traditional Indian norms blasphemous. A few days after the incident, a group of women formed the activist movement on Facebook named "The Pink Chaddi Campaign." Participating in this online meant voicing the rights of women in the modern world. The campaign was considered successful because it formed a community uniting urban women, students, and supporters of human rights in India, and because it became an interest group for public policy in India (Chattopadhyay 2011). The element common to the Palestine and India examples is the discourse of the liberation struggle conducted by young people via technology.

In Indonesia, the use of the internet as the medium for political activism has developed since the 1990s. For the first time, news from the email provider websites was used to mobilize the mass 
who wanted to reform the New Order regime. The reforms of 1998 cannot be separated from the discussion of the development of the internet. From a socio-religious perspective, in the case of Laskar Jihad in Ambon, the internet succeeded in mobilizing the "religious society" to go into the conflict arena in Ambon, Indonesia. Tens of civilians were mobilized through the internet in the warung internet (internet cafes). The internet made the main actors of mujāhid easily accessible by al-Qaeda and Jama'ah Islamiyah (JI), the famous, earlier radical group networking in the Middle East. The cooperation was rejected by Ja'far Umar Thalib, the leader of the mujāhid, but in this case it proved that the internet could make it easier for activists to network and create a new public sphere for conducting their political activism (Lim 2005). Islamic clicktivism aligns with the process of democratization that has occurred in the era of information and technology advancement. The growth of democracy has occurred amid the proliferation of internet use in the wider community (Dahlberg and Siapera 2007). A wide variety of social media has provided equal access in the public sphere, guaranteeing those human rights. The democratic ideals of freedom and equality have become more manifest with the internet, which allows everyone to express their aspirations whenever and wherever.

\section{More Brisk, Less Risk: Proliferation of Islamic Clicktivism}

The internet and its multifarious social media not only more easily facilitate mobilization and participation in classical forms of protest, such as street demonstrations, but also enhance these protests by effectively and rapidly diffusing communication and mobilization efforts. The scholars concerned with online activism have been developing theories, patterns and typologies of online activism movements to simplify the reading of the cases. I will observe the Islamic clicktivism case in Indonesia through the typology theorized by some scholars. First, I will give the distinction between "real" action and "virtual" action in term of online activism. The first term is real action. This kind of activism is just like other traditional activism (street demonstrations). In the cyber era, the "real" activism has the support of internet tools, and is known as "internet-supported" action. "Virtual" action is activism based solely on the internet, as it cannot work without it. Its movement area is only through online social networks, and is known as "internet- 
based" action (Gurak \& Logie 2003; McCaughey and Ayers 2003). In this case, the internet is a new tool and tactic in the activism arena. Some activism movements used the internet as a tool only, and some others use it as a "tool" and an "arena." Some of these tools, such as email, online petition, and web protest, are an extension to existing protest techniques. To summarize, there are two kinds of action in online activism, dependent on the user: internet-supported action and internet-based action.

Online activism can also be classified by participation cost and risk, which is also known as the activism "threshold". According to its participation cost and risk, online activism is classified into two categories: low threshold and high threshold. The reason for classifying by the level of participation is that some analysis indicates the advantage of technology advancement is in the reduction of "transaction costs" associated with organizing collective political action ("Grass Roots in Cyberspace - Bonchek - 1995 | Transaction Cost" n.d.). Low threshold, as a category, is when participation and risk are at a low level. For instance, signing an online petition or broadcasting a warning entails a low cost, as there is minimal commitment and risk, and is therefore identified as having a low participation threshold. To start a street rally protest, the cost of communication may involve too much time and money. It may also involve a violent confrontation with other communities or security forces of the state. Here, the term "high threshold action" is used. Hence, activism amid the advancement of technology and the internet may be seen from two dimensions. The first is internet-supported and/or internet-based, and the second is low threshold and/or high threshold. These two dimensions create four quadrants. Quadrant 1 depicts the typology of internet-supported action with a low threshold, such as the donation of money, consumer behavior, and legal protest demonstrations. Quadrant 2 is internet-supported action with a high threshold. It concerns transnational demonstrations and meetings, and more obstructive actions, such as occupations and (street) blockades. Quadrant 3 is internet-based action with a low threshold. This section concerns solely online actions like petitions, email bombs and virtual sit-ins. This quadrant demonstrates the advantage of the internet in the cases of mobilization and reduction of participation thresholds. Quadrant 4 refers to internet-based action with a high threshold. 
In this last section, the actions are largely or totally dependent on the internet, but demand more resources than signing a petition or "bombing" an email. This includes protest websites, alternative media sites, culture jamming and hacking activism (Van Laer and Van Aelst 2010, 1150-51).

According to this typology, Islamist clicktivism in Indonesia can be categorized in quadrant 3, or internet-based action with a low threshold, where the Islamist clicktivism is performed solely through online networking. Broadcast features in some online social media, including Whatsapp and BlackBerry Messenger, enable activists to take action more efficiently, meaning at a lower cost but with a broad reach, because they can share intensively to colleagues saved in their smartphone contact list. However, this online action can also be real action involving other civil societies. This pattern of online social movement is classified as quadrant 2 , or internet-supported actions with a high threshold. The following discussion explores how virtual action can include real action involving other civil society actors.

Since the beginning of the new millennium, the development of social media in cyber space has grown rapidly. Political activities can be conducted sitting in front of a personal computer. Online petition websites have become a place to support change, through providers such as Change.org. By reading what is shown and clicking (signing), one can support the movement (petition). The term clicktivism is essentially an acronym derived from the virtual action of "clicking," and "activism," or movements of political and identity communication. This term was popularized by Micah White when creating the protest movement Occupy Wall Street (OWS) in mid-2011. He subsequently developed his notion of left-activism in the book, The End of Protest (White 2016).

The term clicktivism is sometimes used to describe activists using social media to organize protests. It allows organizations to quantify their success by tracking how many "clicked" on their petition, or answered some other call to action. The success of a clicktivism campaign can also be indicated by how many "likes" it receives. Clicktivism strives to quantify support, presence and outreach, without putting emphasis on real participation. The act of "liking" a photo on Facebook or clicking a petition is symbolic, as it demonstrates the individual is aware of the situation, and it shows their peers their opinions and thoughts on 
certain subjects. Social media enables contentious politics through blogging and the creation of new social media (White 2016; Radsch 2016).

The dynamic of networking and mobilizing the masses through clicktivism extends beyond clicks and likes. Any activities capable of mobilizing and facilitating networking through a screen can be considered clicktivism. On social media it also includes sharing and broadcasting.

The definition is not the critical factor. More important insights can be discerned from the proliferation of clicktivism in the context of contemporary democracy in Indonesia. Clicktivism signifies the efforts of activists who realize that the world runs on market mechanisms (White 2016), which drags the thinking pattern into the logic of the marketplace. This thinking pattern emphasizes that everyone has the right to promote and offer products freely and easily to the consumer. Along with liberal democracy, the market mechanism is not only developed from the perspective of economic studies, but also as readings for identity studies. The society may enunciate their identity to get the balance and the justice they wish to acquire.

Along with advances in technology, the democratization process of the Era Reformasi enables all identities to be easily spread and socialized across wider society with a single touch. The religious authorities controlled religious identity in the New Order era, with the government filtering the networks. In the post-Soeharto era, the networks no longer have these obstacles, providing everyone with the claim to religious authority. The increase of Islamic clicktivism is part of the rise in the commodification of Islam in the aftermath of the post-Soeharto era, where religious interests meet economic ones. Islamic clicktivism is therefore an effort in political struggle in the wider community.

Online social media aids mass mobilization processes in becoming more democratic. The public can directly consume disseminated news without a complex verification process. Cyber activism movements among Islamist activists in Solo have brought a new pattern of movement in the symbiotic relationship between groups, online social media, print media, and the participant/sympathizer/supporter.

In this study, the internet, as the medium for activism, is considered a convivial medium (Lim 2005). Lim also has argued that cyberspace activism is a convivial effort - characterized by 
convergence, low cost, broad availability, and resistance to control - that provides a broader scope for autonomy, creativity, freedom, and collaboration than previous media (Lim 2012, 130). Taking two cases of internet and political activism, Reformasi (1998) and Laskar Jihad (1999-2001), Lim reveals that the internet in Indonesia is clearly an urban phenomenon, evident in places such as Jakarta, Bandung and Yogyakarta. In this context, the internet's impact on political collective activism in Indonesia must start with the shift of control over information from political elites to techno-elites. The proliferation of techno-elites in some areas in Indonesia has created possibilities for internet-enabled collective action (see Tarrow 1998). Today, the availability of the internet in Indonesia is widening, and not only in big cities. The development of the internet's range has had a massive impact on the transfer of information from "Islamist techno-elites" to the common internet user.

\section{"Share for Care," Networking Ability in Democratic Era}

"Like," "please type amin in comment," and "share" are often seen on social media. These words and phrases are an effort to garner support for the event being promoted and spread through social media. It becomes part of the political activity for network building and gaining mass influence in the public sphere. Network building is frequently discussed in the study of identity politics and social movements. The masses of people networked through social media groups are an informal source, useful for leading into an action. Sidney Tarrow rationalizes the ability and willingness of these informal sources to perform an action. Tarrow states that a militant movement possesses some basic properties of movements that should be maintained. For instance, collective action that has them interrupting, obstructing and opposing as a group, can be shown to another group that does not have the same ideology, or has an attitude in confrontation with Islam. There is also common purpose, which is used to generate group interest. Common purpose is the central justification for the masses to take risks and act collectively in benefit of group solidarity, which can be the feeling of fighting for or sharing the same faith with a community. The militant movement also has collective action defense. They have to defend the group from various challenges by making use of anything in front of them (Tarrow 1998). 
Some scholars argue that the use of social media and informal sources to mobilize the masses is commonly found in less-open societies or enclaves. It is only because of this movement they can defend their activism with the resources grounded in daily social relationships, and cannot be tracked by political opponents or repressive regimes (Wiktorowicz 2004). This argument should be compared with other perspectives, as the identity struggle hidden from the public sphere can only be found in repressive regimes, in contrast with a democratic society. One of the theories for analysing this phenomenon is the that of youth identity and cyber activism, in which the cyber movement mobilizers are 20-40 years of age, part of urban society, and live around the city, with complex problems (Lim 2005; Bayat and Herrera 2010).

From the youth identity and cyber activism perspective, the existence and proliferation of Islamist clicktivism can be equated to the conditions in which a person is trapped in, such as the pressure of social structures and authority relations. These conditions encourage Islamist activists to try to oppose the authorities that control rebellious activity. The expression of identity and the realization of the goals of Islamist activists is influenced by global circumstances and the local process surrounding the identity of Islamist activists (Bayat and Herrera 2010). It can be witnessed in youths with financial stability. They are able to express themselves by going to pub, enjoying hip-hop, rap, or jazz music in the fight against boredom in big cities. They also play on sophisticated gadgets with various applications and gather with friends in cafes. In other cases, the educated youth protest against the authority's policies that they consider to be blocking their interests on the grounds of democracy or low-level social status. Muslim youth have to position two identities. One as free, modern and productive, and the other as Muslim, obeying religious norms.

Because of the need to maintain these two positions, the identity expressions of Muslim youth are different around the world. Some of them express themselves by forming small groups that reflect the two conditions of being young and Muslim. For example, Fun-Da-Mental is a Muslim rap group creating Jihad theme songs in England (Ted Swedenburg, 2010: 291). Other youth groups form protest actions concerning justice issues, to respond to the political situation in some Muslim countries in the Middle East. With Islamic clicktivism, the 
Islamist activists display their identity as modern Muslim youths, showing sensitivity toward social, political, and juridical issues. The Islamist activists think that societal conditions should change significantly. Since they cannot directly participate in these issues, they develop a discourse, and alternative movements to respond political situations considered disadvantageous for the identity of Muslims, as the biggest population in Indonesia.

Islamic clicktivism becomes a safe and easy playground for the Islamist activist to spread the identity discourse. The proliferation of Islamic clicktivism, as with the other Islamist groups in Solo, cannot be realized without the rate of modernization, democratization, and globalization that present the opportunities for wider participation in society. The proliferation of Islamic clicktivism reflects the openness of the democratization process. Participants actualize themselves with methods and devices adjusted to the democratic environment, including forming social movements to actualize the freedom of the civil citizens, building mass networks through the internet, involvement in influencing decisions, and critiquing institutions in a checks and balances process (Ahyar, 2015). In this context, Islamic clicktivism is an effort to enter the public sphere by considering the momentum of social change. The table below demonstrates how the narrative discourses of the Islamist activists' demands are very similar to the narrative discourses of the democratic government.

\begin{tabular}{|l|l|}
\hline Action/Case & Narrative Discourse \\
\hline $\begin{array}{l}\text { Rejection of Iranian } \\
\text { Corner IAIN Surakarta }\end{array}$ & $\begin{array}{l}\circ \text { National stability } \rightarrow \text { Preventing conflict such as in } \\
\text { the Middle East, considered from Syiah }\end{array}$ \\
\hline $\begin{array}{l}\text { Closure of Illegal } \\
\text { Church }\end{array}$ & $\begin{array}{l}\circ \text { Development legality in a juridical country } \\
\circ \text { Peace among religious society }\end{array}$ \\
\hline $\begin{array}{l}\text { Advocate to sporadically } \\
\text { action of anti-liquor } \\
\text { activists }\end{array}$ & $\circ$ National stability \\
& $\circ$ Facilitate the police to reduce crime levels \\
\hline Defense for Siyono, & $\circ$ Justice \\
terrorist suspect & $\circ$ Professionalism of police \\
& $\circ$ Justice \\
& $\circ$ Violation of human rights \\
& $\circ$ Police institution transparency in the democratic era \\
\hline
\end{tabular}

Table 2. Narrative Discourses of Actions

In some respects, the Islamist groups who keep enunciating Islamic clicktivism as well as threatening on behalf of jihad, violate principles of democracy, such as human rights, pluralism, and multiculturalism, 
which grow in step with democracy. To quote Barber, progress moves in steps that sometimes lurch backwards; in history's twisting maze of identity establishment against globalization in the democratic era, jihad not only revolts against but also abets democracy and globalization. Democracy and globalization not only endangers jihad but also recreates and reinforces its appearance. Jihad and McWorld are in opposition but also in need of one another (Barber 2001, 4). Appadurai offers the term technoscapes, which is the carrier of relational change among humans in the context of globalization. Technoscapes bring new types of cultural interactions and exchanges through the power of technology (Appadurai 1990). Technology is indeed very closely related with mass mobilization (especially after an economic impact) because it easily facilitates the process. Technology can delineate the borders among groups, and at once unify one another. Using the smartphone, members of Islamist movements network through online messenger applications (like WhatsApp, Blackberry Messenger, and Line), they bound themselves in an online enclave, separate from the "outsider" of their ideology, and then widely "broadcast" messages regarding their notion of Islamism. They gather, share information, learn and struggle digitally.

Before taking action, the actor in an Islamist group usually collaborates with others similar groups. They invite other Muslim civil society organizations to be involved in their actions and support their movement. When some Muslims assert their support, the Islamist movements often generalize this to suggest they have the support of the broader Muslim population. This discourse is reinforced by the writings in various local mass media, such as the magazine Koran Panji and bulletin Aitam, which are routinely deployed on Friday and can be read widely for free. The easy mobilization process rapidly accelerates their movement in launching an action. They have gathered in a place that is determined to launch political action.

Some scholars (like Oliver Roy) argue that the rejection of modern values by the Islamists, which is a long held view by western countries, has no real relationship with Islamic theology (Roy 1994, 2006, 2007) but is instead a reflection of political and social problems concerned with globalization. Democracy may not detrimental to Islamism ideology. On one hand, the actions of Islamism can be seen as a resistance effort against democracy, but on 
the other hand they are in line with the logic and protest narrative of democracy. Resistance efforts against democracy can be seen more clearly as a phenomenon related to socio-political circumstances rather than theological disagreement. In fact, many of these groups express political arguments wrapped in theological doctrines, when attempting to counter democratic arguments over freedom, justice, equality and public participation. These efforts are carried out solely in order to remain able to follow the democratic stream that drags people into the issues of democracy, and unconsciously also brings the Islamists into the stream. Actually, Islamism is only a minority of Islamic ideology in Indonesia. Nevertheless, through the performances of its activists at both the offline and online level, they come into prominence (Brauchler 2004).

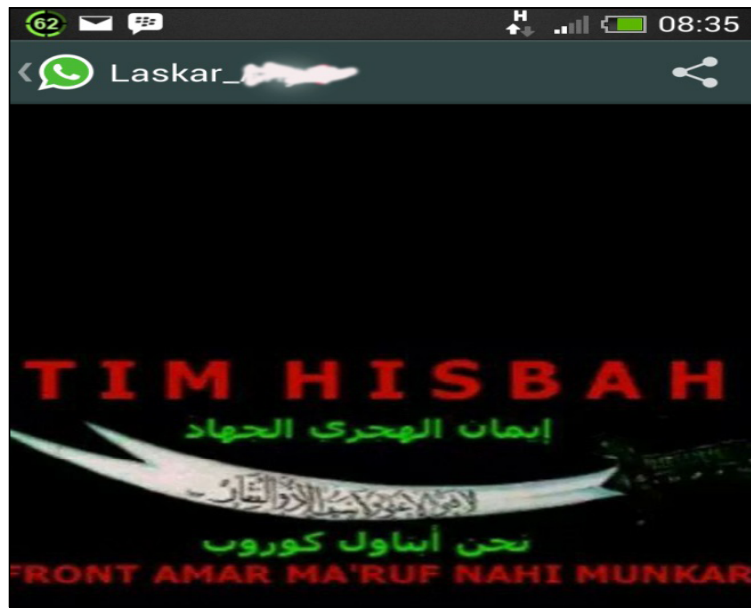

Figure 3. Their own online group for mass mobilization Source: Researcher's Whatsapp contact

The Islamist groups fight for democracy precisely by the argument and logic of democracy. There are five concerns often highlighted by Islamists to deconstruct democracy. Masdar Hilmy calls it "fighting from within." The first argument is concerned with the truth of the claim. The proponents of democracy often stigmatize Islamists as claiming to be the sole keepers of the truth. But in fact, according to Islamists, the proponents of democracy are doing so: they also claim to be the only legitimate holders of the truth by their democratic argument. If something is part of democracy, it is then true, and other is not. Those who want to engage in political struggle (with the exception of democracy), for instance khliäfah 
or monarchy, are immediately described as radical or even terrorists. The second argument concerns the freedom of expression. The Islamists argue that the proponents of democracy, especially in Western countries, are inconsistent in implementing the principle of freedom of expression. They refer to the Muslim phenomenon in some Western countries (such as France) where they (the Muslim people, especially women) are banned merely because they wear Islamic symbols like the veil or bijäb. The third argument is concerned with multiculturalism in democratic countries. Western countries are perceived to force the conditioning of multicultural nuance upon the minority culture. Islamists argue that in some democratic countries, Muslim minority people are forced to devolve their cultural identity and assimilate to the mainstream culture, which they perceive as Christian. If the same kind of assimilation were to be expected from Christians living in Muslim majority countries, the West would raise objections, arguing that minority rights are not respected. The fourth argument concerns the approach to electoral politics. According to the Islamists' argument, the proponents of democracy often use a double standard when establishing and enforcing democracy in the Muslim world. The establishment of democracy is often characterized by the institutionalization of electoral politics, through a general election, for example. But, the proponents of democracy are not ready yet to conduct electoral politics in the Muslim world. They seem to be afraid that Islamists will rise to power in a general election. So, the Islamists parties seem to be forbidden from winning a general election in Muslim countries. The last argument that Islamists are concerned with is about consistency in implementing the principle of secularism, where religion and the state cannot interfere with one another. The Islamists argue that this principle is applied inconsistently in democratic countries. For instance, they ask why some democratic countries intervene in issues of clothing as an expression of Muslim religiosity? Is this a secular principle? (Hilmy 2010). These five arguments are convincing for the notion that the Islamist rejection of democracy is based not merely on normative belief, but also on logic and criticism developed in democratic circumstances. It has meant that the concept of democracy can colour the Islamists' understanding of freedom, which has become a keyword of democracy. Besides, the Islamist movements mainly sound religious reasoning for promoting their identity through the public reason and try to influence some public policies (Ahyar 2015a). 


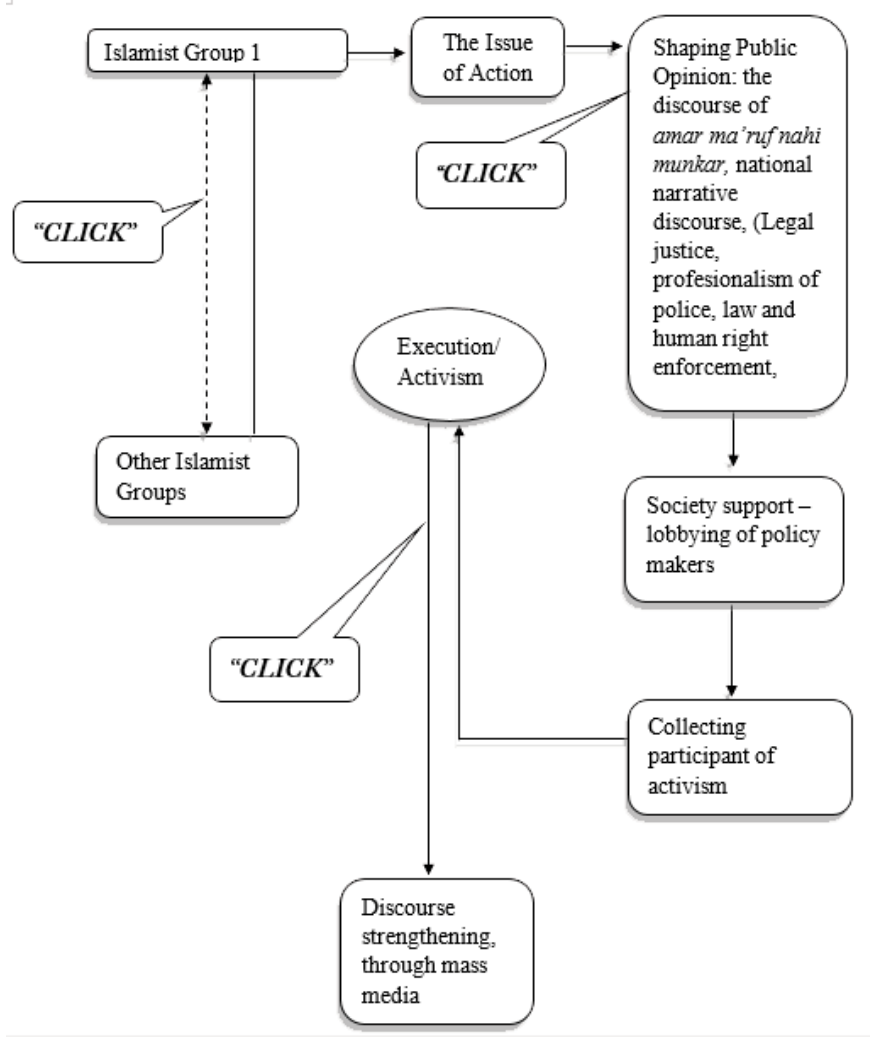

Figure 4. Clicktivism plot

\section{Conclusion}

Islamic clicktivism is basically a socio-religious phenomenon that cannot be separated from technological advancement and the ongoing democratization process in Indonesia. Just like other online marketing agendas that run on market logic in the technological age, Islamic clicktivism arises within the spirit of the commodification of religious identity voiced in the public sphere. Islamic clicktivism signifies some Islamist actors' desires to make their group the only reference of Islamic authority and identity. The purpose of this is to strive to ensure all Muslims refer religious problems to the one, popular Islamic paradigm.

The compatibility of movement patterns in the freedom and openness of democratic society becomes a proliferation factor for Islamic clicktivism in Indonesia. The conviviality of this activity ensures the movement can be long lasting and easily spread to activists 
or Islamist group members. Other civilians may also contribute their solidarity to Islamist activism if there are similar narrative discourses to the national narrative discourse.

As an activism that grew in the process of democratization, modernization and globalization, Islamic clicktivism utilizes the principles and pillars of democracy to perpetuate the struggle and communicate the activist's existence during the development of democracy in Indonesia. It can be seen in the discursive voices of movements, which always highlight national issues in the common interest of Indonesians, such as national security and stability, religious tolerance, supremacy of law, justice, human rights, good governance, and transparent administration. The similarities between Islamist discursive voices and national narrative discourses determine whether movements can become mainstream, and gain support from other movements outside of their ideological boundaries. 


\section{Endnotes}

- The earlier version of this paper has been presented at the International Conference article on Social and Political Sciences at Syarif Hidayatullah State Islamic University Jakarta. I would like to thank to Professor Noorhaidi Hasan for his suggestions to this paper. Special thanks to my great colleagues and friends, Alfitri, Ph.D, Zoltan Pall, Ph.D, Miftahurridho, and some key actors of LUIS for their time in intensive discussion.

1. HIK is an acronym for "Hidangan Istimewa Kota," which is a local term Solo people use to refer to a traditional food stall. In other towns, this is called angkringan. The ikhwan usually hold discussions in this place.

2. For websites with more references, please see: http://www.millahibrahim.net/. Amid the government blocking news sites considered to be radical Islamic movements, the site http://www.millahibrahim.net/ roams free in cyberspace. In terms of SEO (search engine optimization), this website ranks first on several indexes, including Google and Bing, with the keywords "jihad menegakkan taubid" (Jihad uphold Allah monotheism.)

3. Laporan Perkembangan perekonomian Indonesia, "Perkembangan Perekonomian Indonesia, Mengulangi tahun 2008?” format pdf, World Bank, Maret 2011, hlm. 44.

4. The category of Muslim refers to Ayubi's work on political Islam. This category is more easily understood than other scholars' works because Ayubi simplifies Muslim beliefs to their social and political actions.

5. My in-depth interview with Edi Lukito, Chief of Laskar Umat Islam Surakarta. March, 22015.

6. My brief interview with Syamsul Bakri, Vice Dean 3 Faculty of Ushuluddin and Da'wa IAIN Surakarta, December 2014

7. The protest agenda led by Parno, with some residents of Busukan, as well as the representatives of Muslim in Mojosongo, Edi Lukito of Laskar Umat Islam Surakarta, Agus Junaidi of Laskar Hisbah Solo, Helmy Akmad Sakdilah of Nahdlatul Ulama, Suharni as representatives of GKI, Iriansyah Police Commissioner of Solo, Ahmad Purnomo Deputy Mayor of Solo and TNI, Village Head, Politic and Nation Unity, municipal police and journalists.

8. My in-depth interview with Agus Junaidi, the leader of Tim Hisbah (one of the Islamist vigilante groups in Solo), May 2015.

9. Interview with Edi Lukito, Head of Laskar Umat Islam Surakarta. May 2015.

10. The most used online media affiliated with the Islamism ideology in Solo city is http:// www.panjimas.com/, https://www.voa-islam.com/.

11. Muhammadiyah to report Densus 88 to KPKover Siyono case", The Jakarta Post, Retrieved on May 2016

\section{Bibliography}

Ahyar, Muzayyin. 2015a. "Agama, Negara dan Public Reason: Kasus Penutupan Lokalisasi Km 17 Karang Joang Balikpapan Dalam Sudut Pandang Public Reason." Lentera: Jurnal Ilmu Komunikasi Dan Sosial Keagamaan 17 (1). 
Sunan Kalijaga. http://digilib.uin-suka.ac.id/17397/.

2015c. "Membaca Gerakan Islam Radikal dan Deradikalisasi Gerakan Islam.” Walisongo: Jurnal Penelitian Sosial Keagamaan 23 (1):1-26. https:// doi.org/10.21580/ws.2015.23.1.220.

.2015d. "Ahmadiyah dalam Labirin Syariah dan Nasionalisme Ketuhanan di Indonesia." Mazahib: Jurnal Pemikiran Hukum Islam 14 (2). https://doi. org/10.21093/mj.v14i2.340.

—. 2017. "Is Islam Compatible with Democracy? Islamist Movement's Trajectory on Democratization in Indonesia." Walisongo: Jurnal Penelitian Sosial Keagamaan 25 (1):139-72. https://doi.org/10.21580/ws.25.1.1335.

Alfitri. 2008. "Religious Liberty in Indonesia and the Rights of 'Deviant' Sects." Asian Journal of Comparative Law 3:1-27. https://doi.org/10.1017/ S2194607800000144.

2015. "Whose Authority? Contesting and Negotiating the Idea of a Legitimate Interpretation of Islamic Law in Indonesia." Asian Journal of Comparative Law 10 (2):191-212. https://doi.org/10.1017/asjcl.2016.1.

Appadurai, A. 1990. "Disjuncture and Difference in the Global Cultural Economy." Theory, Culture \& Society 7 (2):295-310. https://doi. org/10.1177/026327690007002017.

Ayubi, Nazih. 2003. Political Islam: Religion and Politics in the Arab World. Routledge.

Barber, Benjamin R. 2003. Jihad Vs. McWorld. Corgi.

Bayat, Asef. 2007. Making Islam Democratic: Social Movements and the PostIslamist Turn. Stanford University Press.

Bayat, Asef, and Linda Herrera. 2010. Being Young and Muslim: New Cultural Politics in the Global South and North. Oxford University Press.

Brauchler, Birgit. 2004. "Islamic Radicalism Online: The Moluccan Mission of the Laskar Jihad in Cyberspace." The Australian Journal of Anthropology 15 (3):267-85.

Chadwick, Andrew. 2006. Internet Politics: States, Citizens, and New Communication Technologies. Oxford University Press.

Chattopadhyay, Saayan. 2011. "Online Activism for a Heterogeneous Time: The Pink Chaddi Campaign and the Social Media in India." In Building and Strengthening Communities and Social Networks, Spring, 27:63-68. Pennsylvania.

Dahlberg, Lincoln, and Eugenia Siapera. 2007. Radical Democracy and the Internet: Interrogating Theory and Practice. Basingstoke, U.K.: Palgrave Macmillan. http://trove.nla.gov.au/version/30957937. 
"Grass Roots in Cyberspace - Bonchek - 1995 | Transaction Cost." n.d. Scribd. Accessed April 6, 2017. https://www.scribd.com/doc/82147418/Grass-Rootsin-Cyberspace-Bonchek-1995.

Hasan, Noorhaidi. 2006. Laskar Jihad. SEAP Publications.

2013. The Making of Public Islam Piety, Democracy and Youth in Indonesian Politics. sukapress.

Hilmy, Masdar. 2010. Islamism and Democracy in Indonesia: Piety and Pragmatism. Institute of Southeast Asian Studies.

Kepel, Gilles. 2006. Jihad: The Trail of Political Islam. I.B.Tauris.

Lim, Merlyna. 2005. “@rchipelago Online: The Internet and Political Activism in Indonesia.” Enschede, Netherlands: Twente.

2012. "Life Is Local in the Imagined Global Community: Islam and Politics in the Indonesian Blogosphere." Journal of Media and Religion 11 (3):127-40. https://doi.org/10.1080/15348423.2012.706144.

- 2013. "Many Clicks but Little Sticks: Social Media Activism in Indonesia." Journal of Contemporary Asia 43 (4):636-57. https://doi.org/10. 1080/00472336.2013.769386.

- 2017. "Freedom to Hate: Social Media, Algorithmic Enclaves, and the Rise of Tribal Nationalism in Indonesia." Critical Asian Studies 49 (3):411-27. https://doi.org/10.1080/14672715.2017.1341188.

McCaughey, Martha, and Michael D. Ayers. 2003. Cyberactivism: Online Activism in Theory and Practice. Routledge.

Narciso, Jerson Benia. 2008. "Christianization in New Order Indonesia (19651998): Discourses, Debates, and Negotiations." Melintas 24 (3). http:// journal.unpar.ac.id/index.php/melintas/article/view/943.

Radsch, Courtney C. 2016. Cyberactivism and Citizen Journalism in Egypt: Digital Dissidence and Political Change. Springer.

Rheingold, Howard. 2000. The Virtual Community: Homesteading on the Electronic Frontier. MIT Press.

Roy, Olivier. 1994. The Failure of Political Islam. Harvard University Press.

2006. Globalized Islam: The Search for a New Ummah. Columbia University Press.

- 2007. Secularism Confronts Islam. Columbia University Press.

Sayyid, Bobby S., and Salman Sayyid. 2003. A Fundamental Fear: Eurocentrism and the Emergence of Islamism. Zed Books.

Tarrow, Sidney. 1998. Power in Movement: Social Movements and Contentious Politics. Cambridge University Press. 
Tibi, Bassam. 2002. The Challenge of Fundamentalism: Political Islam and the New World Disorder. University of California Press.

Tilly, Charles. 1978. From Mobilization to Revolution. McGraw-Hill.

Van Laer, Jeroen, and Peter Van Aelst. 2010. "Internet and Social Movement Action Repertoires: Opportunities and Limitations." Information, Communication \& Society 13 (8):1146-71. https://doi.org/10.1080/13691181003628307.

White, Micah. 2016. The End of Protest: A New Playbook for Revolution. Knopf Canada.

Widyantoro, Hary. 2017. "Undemocratic Response Towards Deviant Judgement and Fatwa: Sunni-Shiite Conflict in Sampang, Madura, East Java." Mazabib: Jurnal Pemikiran Hukum Islam 16 (1). https://doi.org/10.21093/mj.v16i1.768.

Wiktorowicz, Quintan. 2004. Islamic Activism: A Social Movement Theory Approach. Indiana University Press.

Wildan, Muhammad. 2008. "Mapping Radical Islamism in Solo: A Study of Proliferation of Radical Islamism in Central Java, Indonesia." Al-Jamiah: Journal of Islamic Studies 46 (1):35-69.

Muzayyin Ahyar, State Institute for Islamic Studies (IAIN) Samarinda, Indonesia. Email: muz.ahyar@gmail.com. 


\section{Guidelines}

\section{Submission of Articles}

tudia Islamika, published three times a year since 1994, is a bilingual (English and Arabic), peer-reviewed journal, and specializes in Indonesian Islamic studies in particular and Southeast Asian Islamic studies in general. The aim is to provide readers with a better understanding of Indonesia and Southeast Asia's Muslim history and present developments through the publication of articles, research reports, and book reviews.

The journal invites scholars and experts working in all disciplines in the humanities and social sciences pertaining to Islam or Muslim societies. Articles should be original, research-based, unpublished and not under review for possible publication in other journals. All submitted papers are subject to review of the editors, editorial board, and blind reviewers. Submissions that violate our guidelines on formatting or length will be rejected without review.

Articles should be written in American English between approximately 10.000-15.000 words including text, all tables and figures, notes, references, and appendices intended for publication. All submission must include 150 words abstract and 5 keywords. Quotations, passages, and words in local or foreign languages should 
be translated into English. Studia Islamika accepts only electronic submissions. All manuscripts should be sent in Ms. Word to: http:// journal.uinjkt.ac.id/index.php/studia-islamika.

All notes must appear in the text as citations. A citation usually requires only the last name of the author(s), year of publication, and (sometimes) page numbers. For example: (Hefner 2009a, 45; Geertz 1966, 114). Explanatory footnotes may be included but should not be used for simple citations. All works cited must appear in the reference list at the end of the article. In matter of bibliographical style, Studia Islamika follows the American Political Science Association (APSA) manual style, such as below:

1. Hefner, Robert. 2009a. "Introduction: The Political Cultures of Islamic Education in Southeast Asia," in Making Modern Muslims: The Politics of Islamic Education in Southeast Asia, ed. Robert Hefner, Honolulu: University of Hawai'i Press.

2. Booth, Anne. 1988. "Living Standards and the Distribution of Income in Colonial Indonesia: A Review of the Evidence." Journal of Southeast Asian Studies 19(2): 310-34.

3. Feener, Michael R., and Mark E. Cammack, eds. 2007. Islamic Law in Contemporary Indonesia: Ideas and Institutions. Cambridge: Islamic Legal Studies Program.

4. Wahid, Din. 2014. Nurturing Salafi Manhaj: A Study of Salafi Pesantrens in Contemporary Indonesia. PhD dissertation. Utrecht University.

5. Utriza, Ayang. 2008. "Mencari Model Kerukunan Antaragama." Kompas. March 19: 59.

6. Ms. Undhang-Undhang Banten, L.Or.5598, Leiden University.

7. Interview with K.H. Sahal Mahfudz, Kajen, Pati, June $11^{\text {th }}$, 2007.

Arabic romanization should be written as follows:

Letters: ', $b, t, t h, j, h, k h, d, d h, r, z, s, s h, s, d, t, z, ', g h, f, q, l$, $m, n, h, w, y$. Short vowels: $a, i, u$. long vowels: $\overline{\mathrm{a}}, \overline{\mathrm{i}}, \overline{\mathrm{u}}$. Diphthongs: $a w$, ay. Tà marbūtāa: t. Article: al-. For detail information on Arabic Romanization, please refer the transliteration system of the Library of Congress (LC) Guidelines. 
ستوديا إسلاميكا (ISSN 0215-0492; E-ISSN: 2355-6145) بحلة علمية دولية محكمة تصدر عن مركز دراسات الإسلام والمجتمع (PPIM) بجامعة شريف هداية الله الإسلامية الحكومية بجاكرتا، تعنى بدراسة الإسلام في إندونيسيا خاصة وفي جنوب شرقي آسيا عامة. وتستهدف المجلة نشر البحوث العلمية الأصيلة والقضايا المعاصرة حول الموضوع، كما ترحب بإسهامات الباحثين أصحاب التخصصات ذات الصلة. وتخضع جميع الأبحاث المقدمة للمجلة للتحكيم من قبل لجنة مختصة. تم اعتماد ستوديا إسلاميكا من قبل وزارة التعليم و الثقافة بجمهورية إندونيسيا باعتبارها دورية علمية (قرار المدير العام للتعليم العالي رقم: 56/DIKTI/Kep/2012).

ستوديا إسلاميكا عضو في CrossRef (الإحالات الثابتة في الأدبيات الأكاديمية) منذ ع ا • ب، و بالتالي سإن جميع المقالات التي نشرها مرقمة حسب معرّف الوثيقة الرقمية (DOI) .

حقوق الطبعة محفوظة عنو ان المر اسلة:

Editorial Office: STUDIA ISLAMIKA, Gedung Pusat Pengkajian Islam dan Masyarakat (PPIM) UIN Jakarta, Jl. Kertamukti No. 5, Pisangan Barat, Cirendeu, Ciputat 15419, Jakarta, Indonesia. Phone: (62-21) 7423543, 7499272, Fax: (62-21) 7408633; E-mail: studia.islamika@uinjkt.ac.id Website: http://journal.uinjkt.ac.id/index.php/studia-islamika

$$
\begin{aligned}
& \text { قيمة الاشتر الك السنوي خارج إندونيسيا: }
\end{aligned}
$$

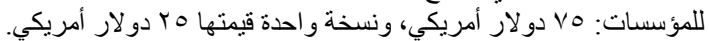

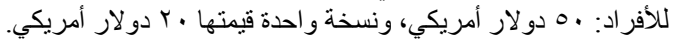

$$
\begin{aligned}
& \text { والقيمة لا تشمل نفقة الإرسال بالبريد الجوي، ونسي. }
\end{aligned}
$$

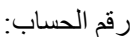

$$
\begin{aligned}
& \text { خارج إندونيسيا (دولار أمريكي): }
\end{aligned}
$$

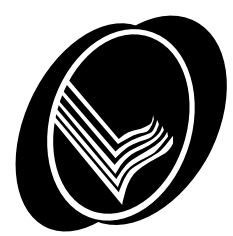




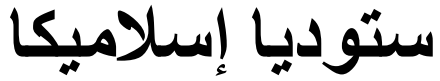 \\ مجلة إندونيسيا للار اسات الإسلامية

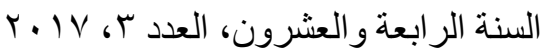

$$
\begin{aligned}
& \text { رئيس التحرير: } \\
& \text { مدير التحرير: }
\end{aligned}
$$

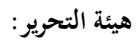

سيف المز اني

جمهاري

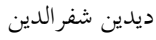

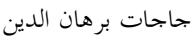

فؤاد جبلي برات مان

علي منحنف

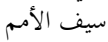

ع مصمة الرفيع

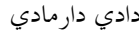

جاجانج جهراني

دين واحد

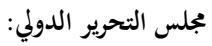

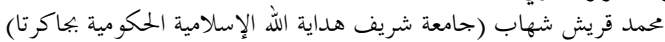

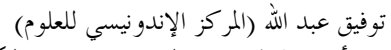

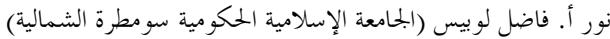
م. ش. ريكليف (جامعة أستر اليا الحكومية كانبيرا) مارتين فان برو نيسين (جامعة أتريخة)

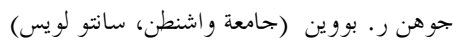
محمد كمال حسن (الجامعة الإسلامية العالمية - ماليزيا) فر كنيا م. هو كير (جامعة أستر اليا الحكومية كانبيرا) إيدوين ف. وير ونجا (جامعة كولونيا، ألمانيا)

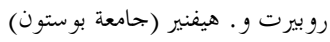

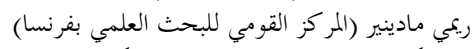

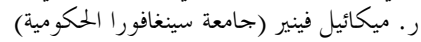
ميكائيل ف. لفان (جامعة فرينشتون)

$$
\text { مساعد هيئة التحرير: }
$$

$$
\begin{aligned}
& \text { مراجعة اللغة الإنجليزية: } \\
& \text { بنيمن ج. فريمان } \\
& \text { دانيل فترسون } \\
& \text { موسى بتول }
\end{aligned}
$$

مراجعة اللغة العربية: أحمدي عثمان العربية 



\section{لالتوايا السالمسيا}



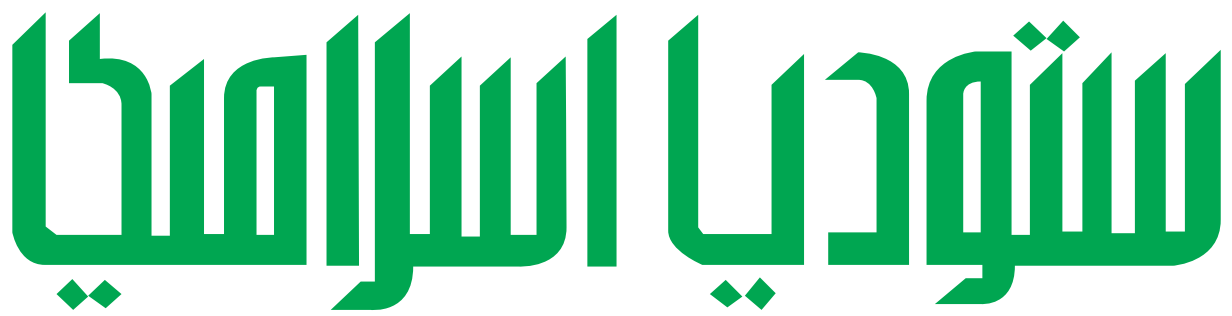

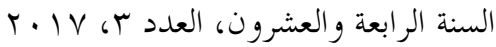

بجلة إنلدونيسية للدراسات الإسلامية

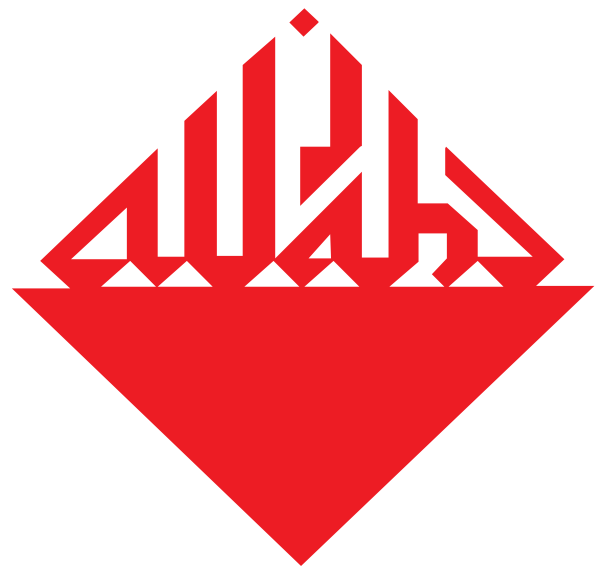

إسلام و ونته نهوسانتخارا:

التمناهنس على الهموية وعلاهتة السلطة

والرهز الدينيه لجمعية نهضة العلماء

محمد نور حارس الدين

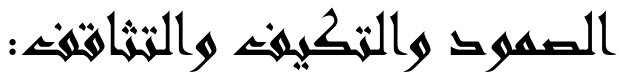

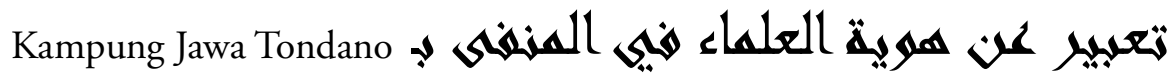

احمد شهيد 